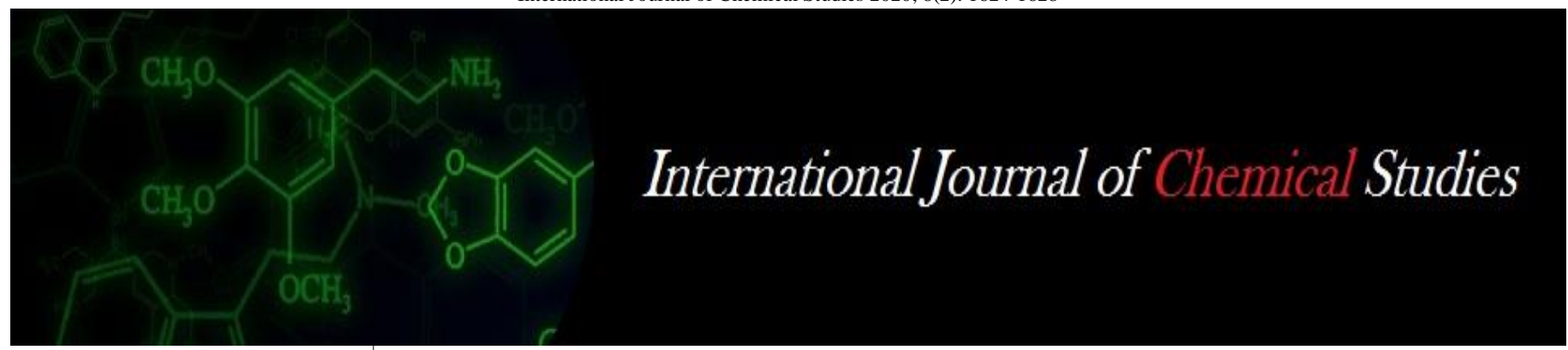

P-ISSN: 2349-8528

E-ISSN: 2321-4902

www.chemijournal.com

IJCS 2020; 8(2): 1624-1628

(C) 2020 IJCS

Received: 03-01-2020

Accepted: 07-02-2020

\section{Arati Ghatole}

Department of Soil Science and Agril. Chemistry, Dr. Panjabrao Deshmukh Krishi Vidyapeeth,

Krishinagar PO, Akola,

Maharashtra, India

\section{AB Age}

Department of Soil Science and Agril. Chemistry, Dr. Panjabrao Deshmukh Krishi Vidyapeeth, Krishinagar PO, Akola,

Maharashtra, India

\section{GS Lahriya}

Department of Soil Science and Agril. Chemistry, Dr. Panjabrao Deshmukh Krishi Vidyapeeth, Krishinagar PO, Akola,

Maharashtra, India

\section{SS Hadole}

Department of Soil Science and Agril. Chemistry, Dr. Panjabrao Deshmukh Krishi Vidyapeeth, Krishinagar PO, Akola,

Maharashtra, India

\section{BJ Gawhale}

Department of Soil Science and Agril. Chemistry, Dr. Panjabrao Deshmukh Krishi Vidyapeeth, Krishinagar PO, Akola,

Maharashtra, India

\section{Corresponding Author:}

\section{Arati Ghatol}

Department of Soil Science and Agril. Chemistry, Dr. Panjabrao Deshmukh Krishi Vidyapeeth,

Krishinagar PO, Akola,

Maharashtra, India

\section{Assessment of molybdenum status in soil of Ratnagiri district}

\author{
Arati Ghatole, AB Age, GS Lahriya, SS Hadole and BJ Gawhale
}

DOI: https://doi.org/10.22271/chemi.2020.v8.i2y.8991

\begin{abstract}
The present investigation was undertaken to the assessment of molybdenum status in soil of Ratnagiri district, The Ninety surface soil samples $(0-20 \mathrm{~cm})$ were collected from the field of major crop in Ratnagiri district of Maharashtra. Ten soil samples from each tehsil from Mandangad, Dapoli, Khed, Chiplun, Guhagar, Ratnagiri, Sanghmeshwar, Lanja and Rajapur from Ratnagiri district were collected and analysed during the 2018-2019. The results indicated that, the physico-chemical properties of soils of Ratnagiri district found to be acidic to neutral in reaction. The electrical conductivity was recorded non saline nature of soil. The calcium carbonate was found in the range of 1.25 to 5.01 per cent. The organic carbon was found medium to high varied from 2.95 to $16.01 \mathrm{~g} \mathrm{~kg}^{-1}$. The available nitrogen was observed low to medium varied from 112.08 to $459.08 \mathrm{~kg} \mathrm{ha}^{-1}$ indicates. The available phosphorus varied from 3.67 to $15.53 \mathrm{~kg} \mathrm{ha}^{-1}$ indicates low available phosphorus status. The available potassium was recorded medium to high status. The nutrient index of available $\mathrm{N}$ was recorded in range from 1.20 to 1.70 , available $\mathrm{P} 1.0$ to 1.20 and available $\mathrm{K}, 2.60$ to 3.00 . Available molybdenum was recorded ranges from 0.01 to $0.64 \mathrm{mg} \mathrm{kg}^{-1}$ the soils of Ratnagiri district. The nutrient index of available molybdenum was recorded 1.88. However the 32.22 per cent soil samples were found deficient in available molybdenum.
\end{abstract}

Keywords: Organic carbon, available n, molybdenum, correlation

\section{Introduction}

Soil is a vital natural resource and should be used judiciously according to its potential to meet the increasing demands of ever growing population. To ensure optimum agricultural production, it is imperative to know the basic facts about our soils and their management to achieve sustainable production. Micronutrients show prominence in Indian agriculture only after their deficiency. Though micronutrients are required in traces but they are just as important as the major. Molybdenum is one of the essential micronutrient required by the plants in small quantity. The concentration and forms of molybdenum in rocks and soils tends to vary according to composition of parent material and their genesis of formation. In acid soils, iron and aluminium hydroxides strongly hold molybdenum Therefore, molybdenum availability continuously increases as soil $\mathrm{pH}$ increases. In some cases, liming alone is sufficient to correct molybdenum deficiency. Soils derived from sands tent to be low in molybdenum content, while soils derived from shale and granite tent to be have higher levels. Molybdenum availability is also generally higher in young volcanic soils and in soils high in organic matters. Molybdenum uptake in the form of molybdate ion $\left[\mathrm{MoO}_{4}{ }^{2-}\right]$, (E.E. Schulte 2004) ${ }^{[15]}$.

Molybdenum deficiency occurs most often in acid, sandy soils and highly weathered soils. Leguminous crops and some vegetables are more likely response to molybdenum than are small grains and other grasses. Low soil $\mathrm{pH}$ induces Mo deficiency which impacts $\mathrm{N}$ fixation and nitrate reduction (Cregan and Conyers, 1989) ${ }^{[5]}$. Molybdenum availability is not routinely assessed anywhere, due to the difficulty of determining accurately very small quantities of Mo. More often, Mo availability is assessed by soil $\mathrm{pH}$. Soils with $\mathrm{pH}$ values of more than 6.0 to 6.5 rarely require molybdenum. Therefore, considering all these facts the present study was undertaken to improve the fertility and productivity of Ratnagiri district. 


\section{Material and Method}

Ratnagiri is one of the coastal district of Maharashtra and form part of Konkan region by covering an area 8208 sq. km. The climate of Ratnagiri district is hot and humid that west coast of India characterized with plentiful and regular rainfall is the most critical factor affecting agriculture in the region. The average annual rainfall in this district is $3047 \mathrm{~mm}$ from south west monsoon during the month of June to September. The main types of soil found in the district are lateritic soil, coastal alluviums and salty soil. The predominant soil in this district is laterite soil which covers 50 to $60 \%$ area and it varies in colour from bright red to brownish red owing to the preponderance of hydrated iron oxide. Ninety soil samples $(0-$ $20 \mathrm{~cm}$ ) representing different soils were collected from nine tehsils of Ratnagiri district viz., Mandangad, Dapoli, Khed, Chiplun, Guhagar, Ratnagiri, Sanghmeshwar, Lanja, and Rajapur. The latitude, longitude and altitude of sampling sites in the study area were recorded with the help of Global Positioning System. The soil samples were processed, air dried and sieved through $2 \mathrm{~mm}$ sieve for different parameters. The soils samples were analysed for important physicochemical properties following the standard laboratory procedure.

The $\mathrm{pH}$ and EC of soil was determined using 1:2.5 soil: water suspension ratio (Jackson,1973) ${ }^{[8]}$, The Soil organic carbon was determined by Walkley and Black wet oxidation method (Jackson,1973) ${ }^{[8]}$, Calcium carbonate estimated by rapid titration method (Piper,1966) ${ }^{[12]}$, available nitrogen was determined by alkaline permanganate method (Subbiah and
Asija,1956) [16], available phosphorus was determined by NH4-HCL method when the $\mathrm{pH}$ below 6.5 (Bray and Kurtz,1945) ${ }^{[1]}$, and $\mathrm{pH}$ above 6.5 it was extracted using the Olsen's extractant $\left(0.5 \mathrm{M} \mathrm{NaHCO}_{3}\right.$ of $\left.\mathrm{pH} 8.5\right)$ as described by Watanabe and Olsen (1965) ${ }^{[18]}$, available potassium was determined by flame photometer using neutral normal ammonium acetate $(\mathrm{pH} \mathrm{7.0)}$ as describe by Knudsen and Peterson (1982) and available molybdenum was determined by grigg's reagent method (Grigg,1953) ${ }^{[7]}$. The data were statistically analysed by using the standard procedure given by Panse and Sukhatme (1985) ${ }^{[11]}$.

\section{Results}

\section{Physico-chemical properties of soil}

The $\mathrm{pH}$ of soil varied from 5.01-6.58 with a mean value of 5.84 (Table 1). Ninety seven per cent of soil samples were found in acidic nature. This might be due to the washing of bases due to heavy precipitation and simultaneous accumulation of iron and aluminium oxides resulting in decrease of silica sesquioxides ratio. The $\mathrm{pH}$ of Panwel area of Konkan region varied from 5.63 to 6.82 reported by Wagh and Sayyed, (2013) ${ }^{[19]}$. The EC of the soil ranges from 0.08 to $0.62 \mathrm{dS} \mathrm{m}^{-1}$ with mean of $0.23 \mathrm{dS} \mathrm{m}^{-1}$ which indicated the low electrical conductivity of the soil. The lowering electrical conductivity might be due to heavy precipitation resulting into leaching of soluble salts in soil. Salvi et al. (2017) ${ }^{[14]}$ reported that, the EC of cashew gardens in Sindhudurg district of Konkan region was in range of 0.04 to $0.15 \mathrm{dS} \mathrm{m}^{-1}$ with an average value of $0.065 \mathrm{dS} \mathrm{m}^{-1}$.

Table 1: The range of physico-chemical properties of soils of Ratnagiri district

\begin{tabular}{|c|c|c|c|c|c|}
\hline \multirow{2}{*}{ S. N. } & \multirow{2}{*}{ Name of Tehsil } & $\mathbf{p H}$ & $\mathbf{E C}$ & $\mathbf{C a C O} \mathbf{3}$ & $\mathbf{O C}$ \\
\cline { 3 - 6 } & & $\mathbf{( 1 : 2 . 5 )}$ & $\mathbf{( d S ~ \mathbf { ~ m } ^ { - 1 } )}$ & $\mathbf{( \% )}$ & $\mathbf{( \mathbf { g ~ k g } ^ { - 1 } )}$ \\
\hline 1. & Mandangad & $5.55-6.58(60.7)$ & $0.16-0.33(0.22)$ & $1.25-4.13(2.59)$ & $4.54-16.01(9.91)$ \\
\hline 2. & Dapoli & $5.1-6.58(5.85)$ & $0.25-0.46(0.30)$ & $1.62-5.01(2.82)$ & $3.19-15.36(8.97)$ \\
\hline 3. & Khed & $5.36-6.4(5.75)$ & $0.12-0.32(0.25)$ & $2.50-3.21(2.84)$ & $3.73-14.26(8.43)$ \\
\hline 4. & Chiplun & $5.22-6.41(5.96)$ & $0.16-0.39(0.20)$ & $1.25-4.52(2.51)$ & $3.49-15.64(9.70)$ \\
\hline 5. & Guhagar & $5.01-6.04(5.80)$ & $0.14-0.48(0.21)$ & $1.37-3.88(2.48)$ & $2.95-11.29(7.98)$ \\
\hline 6. & Ratnagiri & $5.42-6.11(5.81)$ & $0.15-0.35(0.24)$ & $1.31-4.29(2.31)$ & $4.89-13.68(9.81)$ \\
\hline 7. & Sanghmeshwar & $5.53-6.16(5.85)$ & $0.10-0.62(0.28)$ & $2.01-2.87(2.38)$ & $3.85-14-87(8.90)$ \\
\hline 8 & Lanja & $5.27-6.42(5.85)$ & $0.08-0.26(0.17)$ & $2.12-3.10(2.59)$ & $3.68-12.19(9.30)$ \\
\hline 9 & Rajapur & $5.01-6.13(5.64)$ & $0.08-0.40(0.23)$ & $1.86-3.89(2.69)$ & $3.78-15.05(9.89)$ \\
\hline & District & $5.01-6.58(5.84)$ & $0.08-0.62(0.23)$ & $1.25-5.01(2.57)$ & $2.95-16.01(9.21)$ \\
\hline
\end{tabular}

*Figures in parenthesis are mean value

The calcium carbonate content ranged from 1.25-5.01 per cent with mean value of 2.57 per cent for the district (Table 1 and Fig 1). This might be due to leaching of bases like calcium from soil which indicate non- accumulation of $\mathrm{CaCO}_{3}$ in surface soil. Rajeshwar and Khan (2007) ${ }^{[13]}$ reported that, the calcium carbonate ranging from 0 to 2 per cent, due to leaching of exchangeable $\mathrm{Ca}^{++}$. The overall range of organic carbon content was from 2.95 to $16.01 \mathrm{~g} \mathrm{~kg}^{-1}$ with mean value of $9.21 \mathrm{~g} \mathrm{~kg}^{-1}$ was medium to high. High amount of organic carbon in these soils might be attributed to addition of biomass in terms of leaf litter, crop residues and cover crops helps in accumulation of organic matter in these soils. Borkar et al. (2017) ${ }^{[4]}$ observed that the organic carbon in lateritic soil of Konkan region varied from $5.1 \mathrm{~g} \mathrm{~kg}^{-1}$ to $18.0 \mathrm{~g} \mathrm{~kg}^{-1}$. 


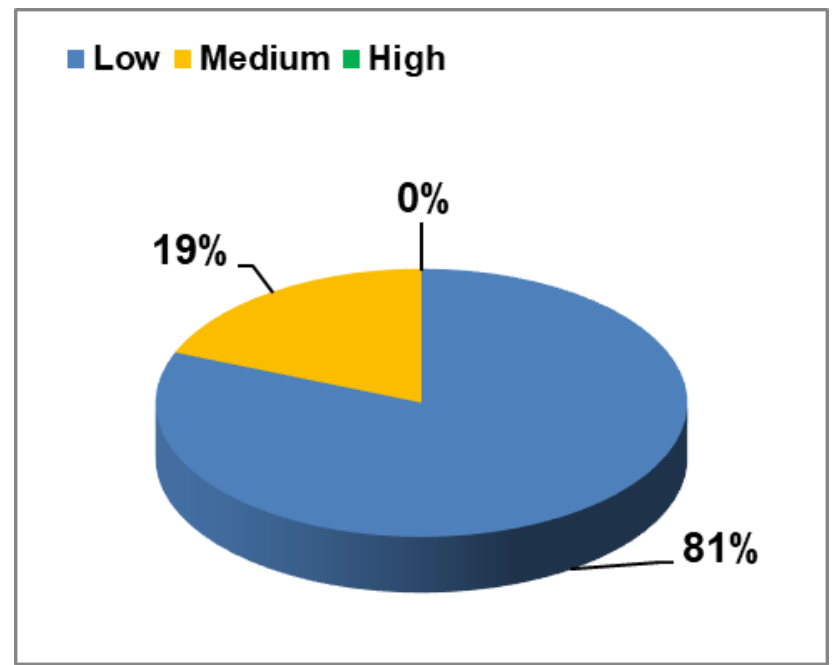

Calcium carbonate

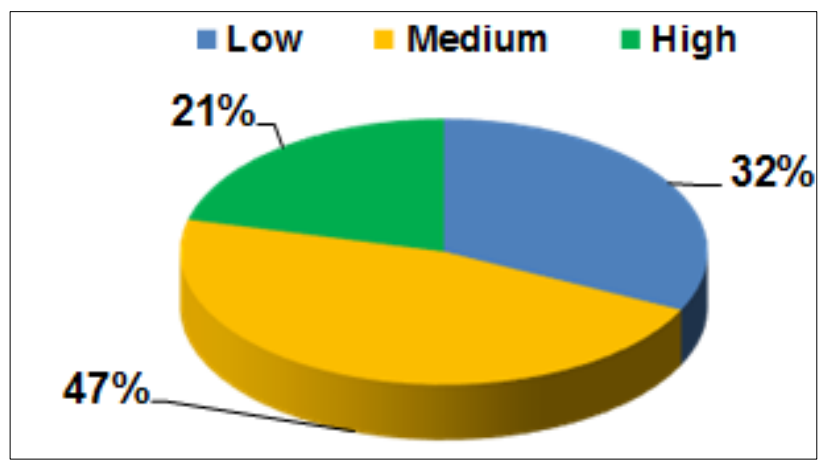

Available molybdenum

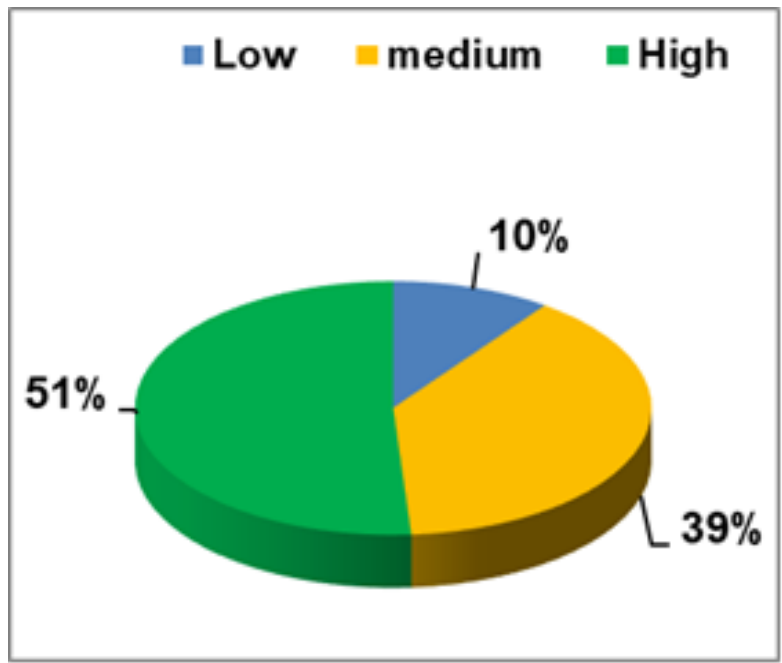

Organic carbon

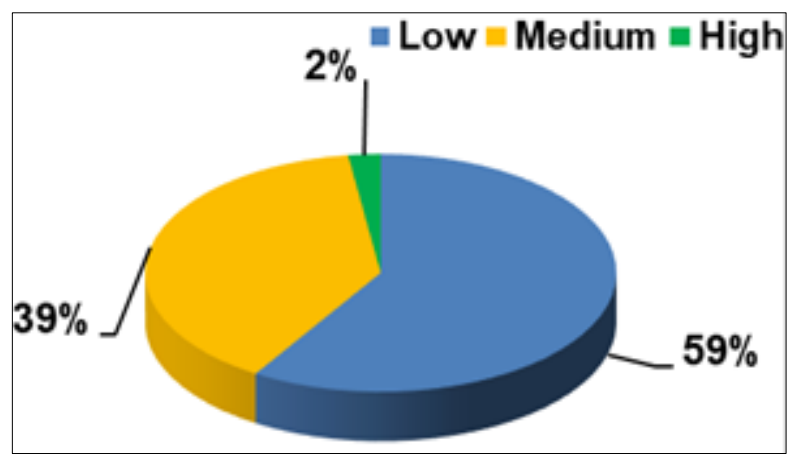

Available nitrogen

Fig 1: Status of calcium carbonate and organic carbon content in soils of Ratnagiri district

Available major nutrient status of soils

The available nitrogen was recorded in ranged from 112.0 to $459.0 \mathrm{~kg} \mathrm{ha}^{-1}$ with mean value of $271.9 \mathrm{~kg} \mathrm{ha}^{-1}$ (Table 2). The sufficient amount of nitrogen content in the lateritic soils might be due to high content of organic carbon which on mineralization released higher nitrogen content. Deshmukh et al. (2018) ${ }^{[6]}$ reported that the available nitrogen content in soil of Ratnagiri ranged from 107.32 to $602.11 \mathrm{~kg} \mathrm{ha}^{-1}$. The available phosphorus was recorded in very low category with range of 3.67 to $15.53 \mathrm{~kg} \mathrm{ha}^{-1}$. These results were conformity with Badrinath et al. (1986) ${ }^{[2]}$ they observed that, the soils might be attributed to their high fixing capacity which prevents phosphorus to come into readily available form into the soil solution revealed by. The available potassium varied from 146.27 to $625.81 \mathrm{~kg} \mathrm{ha}^{-1}$ indicated medium to high available potassium status. The sufficient quantity of potassium in these soils may be attributed to presence of higher quantity of potassium bearing minerals in the parent material. The carbon and potassium stocks in soils of Konkan, Maharashtra and observed the soils of Konkan stores $690 \mathrm{~kg}$ $\mathrm{ha}^{-1}$ potassium in first $30 \mathrm{~cm}$ depth of soils reported by Bhattacharyya et al. (2016) ${ }^{[3]}$.

Table 2: Range and mean value of available nutrient status of soils of Ratnagiri district

\begin{tabular}{|c|c|c|c|c|}
\hline \multirow{2}{*}{ S. N. } & \multirow{2}{*}{ Name of Tehsil } & $\mathbf{N}$ & \multicolumn{2}{|c|}{$\mathbf{\text { P }}$} \\
\cline { 3 - 5 } & & \multicolumn{3}{|c|}{$\mathbf{~}$} \\
\hline 1. & Mandangad & $186.4-459.0(306.91)$ & $3.67-9.72(6.90)$ & $231.8-568.2(432.90)$ \\
\hline 2. & Dapoli & $175.6-385.9(273.28)$ & $5.01-10.68(7.35)$ & $176.8-388.9(288.68)$ \\
\hline 3. & Khed & $138.3-356.2(251.0)$ & $5.59-12.19(8.39)$ & $181.2-372.3(283.77)$ \\
\hline 4. & Chiplun & $186.3-368.3(296.27)$ & $6.34-10.56(8.45)$ & $170.6-507.5(374.33)$ \\
\hline 5. & Guhagar & $112.0-380.3(240.80)$ & $8.26-11.27(9.37)$ & $227.9-492.6(397.82)$ \\
\hline 6. & Ratnagiri & $163.0-379.2(269.64)$ & $6.22-15.53(9.60)$ & $311.5-625.8(473.09)$ \\
\hline 7. & Sanghmeshwar & $153.0-436.2(308.75)$ & $5.89-10.99(8.12)$ & $194.7-471.7(372.04)$ \\
\hline 8 & Lanja & $112.8-344.1(259.49)$ & $8.12-10.23(9.19)$ & $160.4-544.8(293.24)$ \\
\hline 9 & Rajapur & $179.2-396.6(275.44)$ & $5.03-9.66(7.20)$ & $220.2-468.1(288.88)$ \\
\hline & District & $112.0-459.0(271.96)$ & $3.67-15.53(8.28)$ & $146.2-625.8(356.08)$ \\
\hline
\end{tabular}

*Figures in parenthesis are mean value

\section{Available molybdenum status of soils}

Available molybdenum varied from 0.01 to 0.64 with mean of $0.29 \mathrm{mg} \mathrm{kg}^{-1}$ (Table 3). The nutrient index was recorded 1.88 and 32.22 per cent soil samples were deficient in available molybdenum (Fig.2). The similar findings have been also reported by Velmurigan et al. (2013) [17] studied the molybdenum status in soils of Madurai and Sivagangai districts of Tamil Nadu. 
Table 3: Available molybdenum status of soils of Ratnagiri district

\begin{tabular}{|c|c|c|c|c|c|c|}
\hline Sr. No. & Name of Tehsil & Mo $\left(\mathbf{m g ~ k g}^{-1}\right)$ & No. of low soil samples & No. of Medium soil samples & No. of high soil samples & Nutrient indices \\
\hline 1. & Mandangad & $0.02-0.59(0.30)$ & $4(40.00)$ & $3(30.00)$ & $3(30.00)$ & 1.90 \\
\hline 2. & Dapoli & $0.03-0.61(0.30)$ & $2(20.00)$ & $6(60.00)$ & $2(20.00)$ & 2.00 \\
\hline 3. & Khed & $0.05-0.64(0.31)$ & $3(30.00)$ & $5(50.00)$ & $2(20.00)$ & 1.90 \\
\hline 4. & Chiplun & $0.07-0.57(0.38)$ & $2(20.00)$ & $4(40.00)$ & $4(40.00)$ & 2.20 \\
\hline 5. & Guhagar & $0.01-0.61(0.37)$ & $3(30.00)$ & $3(30.00)$ & $1(10.00)$ & 2.10 \\
\hline 6. & Ratnagiri & $0.07-0.55(0.23)$ & $4(40.00)$ & $5(50.00)$ & $0(0.00)$ & 1.70 \\
\hline 7. & Sanghmeshwar & $0.08-0.48(0.25)$ & $4(40.00)$ & $6(60.00)$ & $3(30.00)$ & 2.60 \\
\hline 8 & Lanja & $0.07-0.58(0.29)$ & $2(20.00)$ & $5(50.00)$ & $0.00)$ & 1.50 \\
\hline 9 & Rajapur & $0.03-0.49(0.21)$ & $5(50.00)$ & $5(50.00)$ & $19(21.11)$ & 1.88 \\
\hline
\end{tabular}

Table 4: Karl Pearson's correlation coefficients of available molybdenum with various soil properties

\begin{tabular}{|c|c|c|}
\hline Sr. No & Parameters & Available Molybdenum \\
\hline 1 & $\mathrm{pH}$ & $0.780^{* * *}$ \\
\hline 2 & Organic carbon & $-0.585^{* *}$ \\
\hline 3 & Available nitrogen & $-0.465^{* *}$ \\
\hline 4 & Available phosphorus & $0.489^{* *}$ \\
\hline
\end{tabular}

*- significant at $5 \%$ level $* *$ - significant at $1 \%$ level

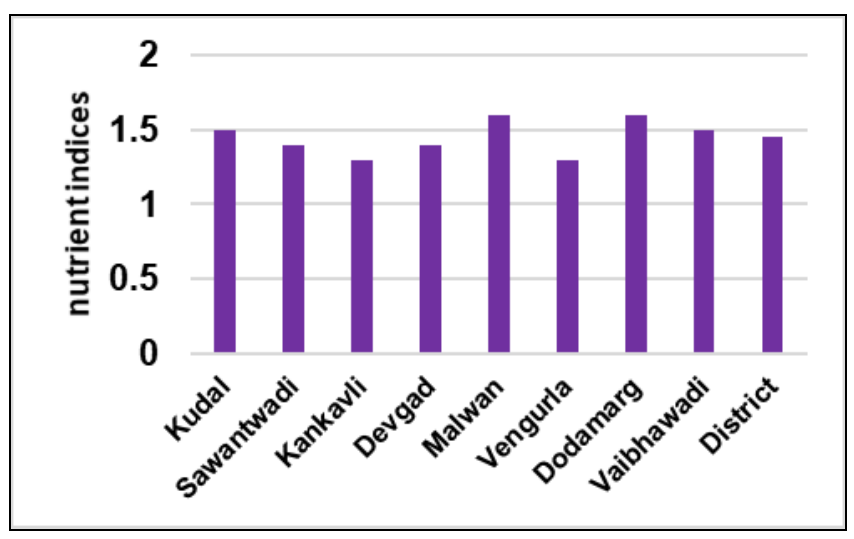

Nutrient indices of available nitrogen

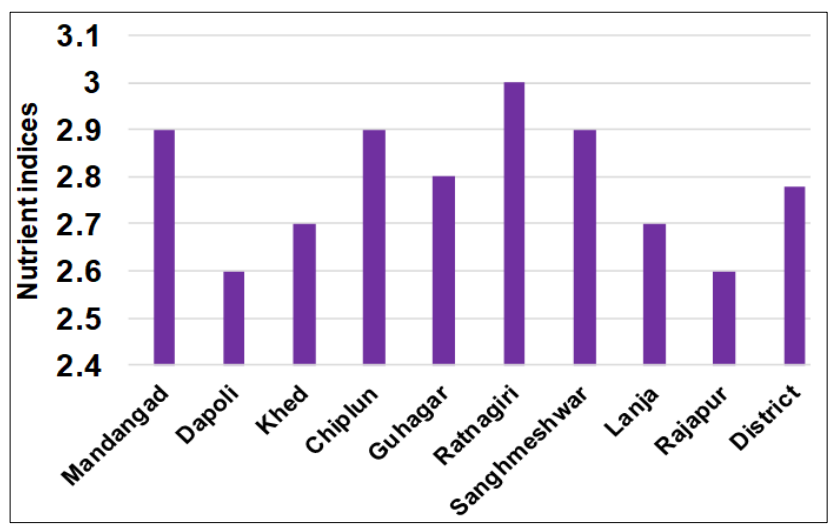

Nutrient indices of available potassium

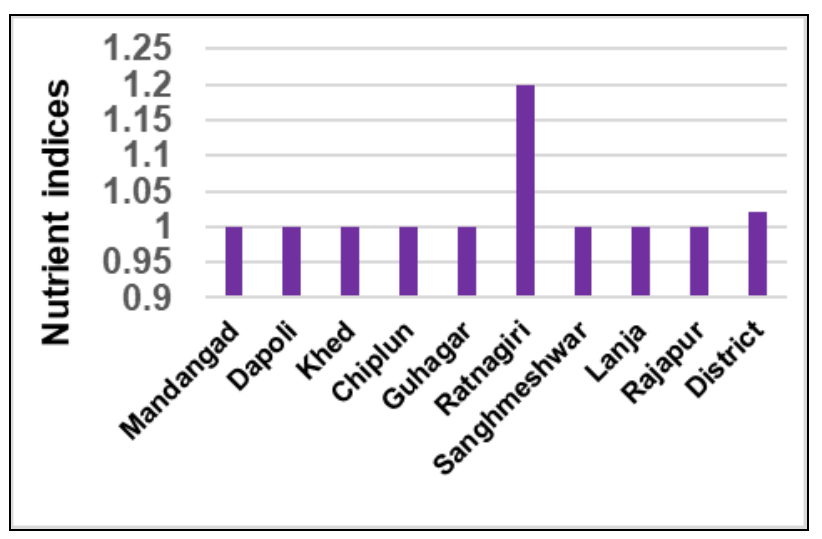

Nutrient indices of available phosphorus

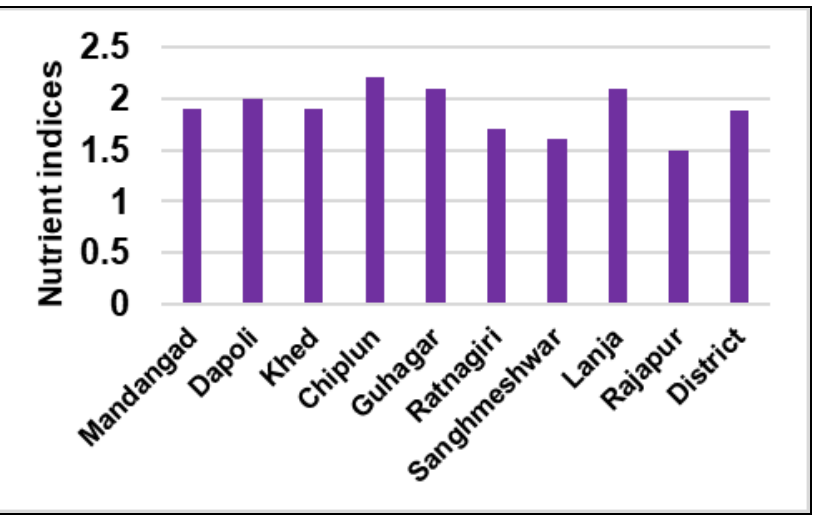

Nutrient indices of available molybdenum

Fig 2: Nutrient indices of available nutrient status if soils of Ratangiri Disrict

\section{Correlation}

The significant and positive correlation of available molybdenum with $\mathrm{pH}(\mathrm{r}=0.780 * *)$, and available phosphorus $(\mathrm{r}=0.489 * *)$ were found soils of Ratnagiri district. The similar significantly positive relationship between available soil $\mathrm{pH}$ with available molybdenum was also reported by Lindsay (1972) ${ }^{[9]}$.

The significant and negative correlation of available molybdenum with organic carbon $\left(\mathrm{r}=-0.585^{* *}\right)$ and available nitrogen $\left(\mathrm{r}=-0.465^{* *}\right)$ was recorded in Ratnagiri district. The similar significantly negative relationship between available molybdenum and organic carbon was reported by More et al. (1976) ${ }^{[10]}$ in Parbhani district of Maharashtra.

\section{Conclusion}

It is concluded that, the available molybdenum status of Ratnagiri district ranges from 0.01-0.64 $\mathrm{mg} \mathrm{kg}^{-1}$. However the 32.22 and 38.75 percent deficiency was recorded of available molybdenum. The nutrient index for available molybdenum was recorded 1.88 for Ratnagiri district. 


\section{Reference}

1. Bray RH, Kurtz LT. Determination of total organic and available form of phosphorus in soil. Journal of Soil Sci. 1945; 59:39-44, 353-357.

2. Badrinath A, Krishnappa M, Patil BN, Kenchaiah K, Rao KB. Fertility Status Of some Typical soils of coastal Karnataka, Journal of the Indian Society of Soil Science. 1989; 34(2):436-438.

3. Bhattacharyya TSS, Prabhudesai MC, Kasture KD, Patil DN, Jagtap VK, Patil DP et al. Carbon and Potassium Stocks in Soils of Konkan, Maharashtra. State level Seminar on, "Development in Soil Science: Climate change and its influence in natural resource management", 2016.

4. Borkar VS, Gokhale NB, Dhopavkar RV, Khobragde $\mathrm{NH}$, More SS, Kasture MC. Distribution of nutrients in different soil types in Konkan region of Maharashtra. International Journal of chemical Studies. 2017; 6(1):275-279.

5. Cregan PD, Hirth JR, Conyers. Amelioration of soil acidity by liming and other amendment. Journal of Soil Acidity And Plant Growth, ed. A. D. Robson, 1989, 205$264 \mathrm{p}$.

6. Deshmukh SV, Ahire PG, Gajbhiye RC, Haldvnekar PC. Available nutrient and fertility status of soils of Ratnagiri district. International Journal of Chemical Studies. 2018; 6(2):1246-1247.

7. Grigg JL. Determination of available molybdenum in soils, N.Z. Soil News. 1953; 3:37-40.

8. Jackson ML. Soil Chemical Analysis, Prentice Hall of India Private Ltd., New Delhi, 1973, 134-182.

9. Lindsay WL. Inorganic phase equilibria of micronutrients in soils. In: JJ Mortvedt, PM Giordano and W L Lindsay (eds), Micronutrients in agriculture. Journal of Soil Science Society of America, Madison, Wisconsin, USA, 1972, 41-57p.

10. More SD, Mali CV, Badhe NN. Status of Zinc and molybdenum in soils from Parbhani district of Maharashtra J. Maharashtra Agric. Univ. 1976; 1:203206.

11. Panse VG, Sukhatme PV. Statistical Methods for Agriculture Workers. ICAR, New Delhi, 1985, 14-33p.

12. Piper CS. soil and plant analysis, Hans. Pub. Bombey. Asian Ed. Akola, 1966, 368-374.

13. Rajeshwar M, Khan MA. Physico chemical and nutrient status of forest soils of Nizamabad, India. An Asian J. Soil Sci. 2007; 2(2):44-47.

14. Salvi VG, Gajbhiye RC, Pawar SS. Nutritional status of cashew gardens in sindhudurg district of Konkan region (M.S). International journal of Chemical Studies. 2017; 5(6):1594-1597.

15. Schulte EE. Understanding plant nutrients: Soil and Applied Molybdenum. A3555, University of WisconsinExtension, Cooperative extension, 2004.

16. Subbaiah BV, Asija GL. A rapid procedure for estimation of available nitrogen in soils. Journal of Current Studies. 25:259-260. Journal of Soil Science and Plant Nutrition. 1956; 9(1):55-68.

17. Velmurugan R, Mahendran PP, Wani SP, Uttam K, Prabhavati M. Molybdenum Status and Critical limit in the soil for green gram (Vigna radiate) growing in Madurai and Sivagangai districts of Tamil Nadu, India. Journal of Soil Sci and Pl. Nut. 2013; 59:229-236.

18. Watanabe FS, Olsen SR. Test for ascorbic acid method for determining phosphorous in water and sodium bicarbonate extract of soil. Proc. Soil Sci. Am. 1965; 29:677-688.

19. Wagh GS, Sayyed MRG. Assessment of macro and micro nutrient soils from Panvel area of Maharashtra India. J. of Environ. Res. and Tech. 2013; 3(1):72-78. 